\title{
Pelatihan Akuntansi Aset Tetap Di Pondok Pesantren 'NH' Kabupaten Lombok Barat
}

\author{
Sapto Hendri Boedi Susetyo*, Siti Atikah, Nur Fitriyah \\ Fakultas Ekonomi dan Bisnis, Universitas Mataram, Indonesia
}

Kata Kunci:
Pondok
pesantren,
pedoman
akuntansi, aset
tetap

\begin{abstract}
Abstrak: Pondok Pesantren merupakan salah satu lembaga pendidikan yang diakui oleh negara Indonesia. Untuk menunjang terlaksananya pendidikan yang bermutu, pesantren wajib menerapkan pengelolaan lembaga berdasarkan Standar Nasional Pendidikan yaitu kemandirian, kemitraan, partisipasi, keterbukaan dan akuntabilitas. Kegiatan pengabdian kepada masyarakat ini, bertujuan untuk membimbing bendahara pesantren atau kader yang ditunjuk sebagai pembantu bendahara agar mampu melakukan pencatatan atas aset tetap pesantren dengan benar, sesuai dengan pedoman akuntansi pesantren yang telah ditetapkan. Bagian terbesar dan terpenting dari aset pesantren adalah aset tetap, khususnya tanah. Mengapa? Memerlukan upaya yang keras, untuk membedakan apakah aset ini milik pesantren ataukah milik pribadi dari pendiri atau pemimpin pesantren atau keluarganya. Pelaksanaan kegiatan ini diawali dengan mengidentifikasi bentukbentuk aset tetap yang dimiliki oleh pesantren dan dilanjutkan dengan penentuan nilai wajarnya. Identifikasi aset ini menggunakan observasi lapangan dan wawancara. Kegiatan dilanjutkan dengan pemberian materi dan penerapan pencatatan akuntansi aset tetap menggunakan data yang telah dikumpulkan pada pelatihan sebelumnya. Hasil dari kegiatan ini adalah tersedianya daftar aset tetap beserta saldo awalnya, serta pemahaman pembantu bendahara terhadap akuntansi aset tetap sesuai dengan pedoman akuntansi pesantren yang berlaku di Indonesia.
\end{abstract}

\section{Korespondensi: saptohendri@unram.ac.id}

\section{PENDAHULUAN}

Pesantren merupakan lembaga pendidikan agama Islam yang tertua. Berawal dari tempat warga belajar mengkaji agama, kemudian berkembang hingga membutuhkan tempat menginap. Keberadaan pondok pesantren sebagai lembaga pendidikan diakui dalam UndangUndang nomor 20 tahun 2003 mengenai Sistem Pendidikan Nasional. Saat ini pondok pesantren dianggap satu-satunya lembaga pendidikan yang tetap eksis membentuk karakter dan kepribadian (Arifin, n.d.).

Pondok pesantren memiliki dua ciri khas. Ciri khas pertama dilihat dari fisik sarana, antara lain, bangunan masjid sebagai sentra kegiatan, asrama untuk santri dan guru, tempat tinggal Kyai dan keluarga, dapur umum serta bangunan sekolah (Shiddiq, 2015). Bangunan pesantren pada umumnya terletak di atas tanah milik pendiri yang kemudian diwakafkan. Selain keberadaan fisik, ciri khas yang melekat dalam pesantren adalah jalinan hubungan 'asah-asih-asuh' yang melibatkan santri, guru, karyawan dan pimpinan pesantren dalam 24 jam, bahkan masyarakat sekitar dapat terlibat. Dari hanya satu bangunan, atau beberapa santri dan guru, pesantren akan berkembang menjadi beberapa bangunan, ribuan santri hingga puluhan guru. Dari hanya satu madrasah diniyah berkembang menjadi madrasah aliyah hingga ma'had 'ali.Semakin berkembang suatu pesantren, tantangan yang muncul kemudian 
adalah struktur pembiayaan yang makin kompleks, latarbelakang sosial-ekonomi santri yang beragam dan kompetensi profesional tenaga pendidik (Anwar, 2004).

Salah satu pandangan KH. Imam Zarkasyi dalam mengembangkan pondok pesantren Darussalam- Gontor adalah manajemen pesantren yang lebih baik (Subekti, n.d.). Dalam pandangan ini, KH. Imam Zarkasyi menginginkan pesantren sebagai suatu lembaga, harus dikelola secara profesional, layaknya suatu badan usaha. Pengelolaan yang profesional bukan hanya di sisi pendidikan, namun juga di sisi keuangan pondok pesantren, termasuk mempertanggungjawabkan seluruh kegiatan dalam laporan keuangan. Hal ini sejalan dengan kewajiban pesantren yang disebutkan dalam Standar Nasional Pendidikan, yaitu mewujudkan kemandirian, kemitraan, partisipasi, keterbukaan dan akuntabilitas.

Semua pondok pesantren mampu menyusun keterbukaan dan akuntabilitas atas dana yang diterima dari berbagai sumber pendanaan. Namun, masih banyak manajemen dan administrasi pesantren yang dikelola secara sederhana dan bersifat kesederhanaan (Yasid, et al., 2018). Pondok pesantren NH Kabupaten Lombok Barat telah berdiri lama. Manajemen pengelolaan pondok pesantren NH telah memisahkan antara manajemen pesantren dengan kyai sebagai figur pemilik atau pendiri pesantren. Pondok pesantren $\mathrm{NH}$ telah menyusun laporan penerimaan dan pengeluaran kas, namun belum dilengkapi dengan daftar harta yang dimiliki oleh pesantren. Daftar harta menjadi salah satu bagian dalam laporan keuangan. Daftar harta ini penting bagi pesantren, sebagai bentuk pertanggungjawaban atas penggunaan dana yang diterima, kemampuan pesantren menyediakan sarana dan prasarana pendidikan bagi santri, kemampuan pesantren meningkatkan mutu pendidikan, serta menunjukkan perkembangan pesantren dari waktu ke waktu.

Kegiatan pengabdian masyarakat pada Pondok Pesantren NH (PPNH) di Kabupaten Lombok Barat bertujuan untuk membimbing bendahara atau pengelola keuangan PPNH dalam menyusun daftar aset tetap pesantren. Hasil yang diharapkan dari kegiatan ini adalah tersedianya tenaga yang terlatih dalam menyusun daftar aset tetap pesantren serta mencatat transaksi atau kejadian yang terkait dengan penambahan, pemeliharaan dan pengurangan aset tetap Analisis Situasi

\section{METODE KEGIATAN}

Kegiatan pelatihan aset tetap ini dilaksanakan mulai bulan Agustus 2018 hingga Mei 2019, di PPNH Kabupaten Lombok Barat. Kegiatan dimulai dengan mempelajari pencatatan kas yang tersedia di PPNH, dilanjutkan dengan indentifikasi aset tetap. Proses identifikasi dilakukan dengan observasi pada obyek sarana dan prasarana yang ada di PPNH. Observasi menggunakan kertas kerja sebagai panduan lapangan. Kertas kerja berisi informasi nama sarana atau prasarana, misal nama bangunan sekolah; luas bangunan; umur bangunan; keterangan kondisi fisik, serta sumber pembiayaan. Proses berikutnya adalah penentuan nilai perolehan awal aset tetap. Proses kedua ini dilakukan dengan cara wawancara kepada pihak bendahara atau yang mewakili, serta didukung dengan dokumen transaksi atau peraturan pemerintah daerah mengenai standar harga minimal. Tahapan berikutnya adalah mempraktikkan jurnal penerimaan, pemakaian dan pemeliharaan aset tetap. 


\section{HASIL DAN PEMBAHASAN}

Pondok pesantren NH yang berlokasi di Kabupaten Lombok Barat, terdiri dari dua bagian, pondok putra dan pondok putri. Kedua lokasi ini tidak berjauhan letaknya. Hal pertama yang perlu diyakinkan dalam penelusuran aset ini adalah ijin pendirian yayasan serta struktur organisasi yayasan dan pondok pesantren.

Tahapan mengenali pondok pesantren dari sisi bentuk hukum dan struktur organisasi menjadi titik awal dalam masa pelatihan. Tahapan ini untuk menentukan apakah pondok pesantren sebagai suatu entitas pelaporan (Indonesia \& Indonesia, 2018). PPNH didirikan dibawah naungan suatu yayasan. Sesuai dengan Peraturan Menteri Agama Nomor 3 Tahun 1979, PPNH merupakan pondok pesantren yang menyelenggarakan sistem pondok pesantren dan sekaligus sistem sekolah atau madrasah (Indonesia \& Indonesia, 2018). Dalam struktur organisasi, yayasan PPNH dipimpin oleh seorang Kyai. Selain bidang pendidikan, PPNH juga memiliki unit usaha ekonomi untuk peningkatan kesejahteraan guru dan pegawai serta pengembangan pesantren sendiri.

PPNH menyelenggarakan pendidikan dengan sistem sekolah dan sistem pondok sekaligus. Dalam struktur yayasan, PPNH terbagi menjadi PPNH putra dan PPNH putri (pada penjelasan berikutnya akan disebut dengan asrama putra dan asrama putri). Setiap asrama dipimpin oleh Kyai yang berbeda dan struktur kepengurusan yang berbeda. Sistem pendidikan PPNH menggunakan sistem KMI (Kulliyatul Muallimin al-Islamiyah). KMI merupakan sistem pendidikan menengah selama 6 tahun, atau setara dengan 3 tahun di tingkat tsanawiyah dan 3 tahun di tingkat aliyah. KMI memadukan semua unsur pendidikan, tidak hanya sekedar susunan mata pelajaran (Alhamudin, $1428 \mathrm{H}$ ). Selain pendidikan tingkat menengah, PPNH juga menyelenggarakan pendidikan tingkat dasar, yaitu madrasah ibtidaiyyah. Pola sistem pendidikan yang dianut oleh PPNH ini diikuti pula dalam struktur pengelolaan keuangan, pengasuhan santri dan pengembangan ekonomi pesantren.

Pencatatan atas penerimaan dan pengeluaran kas di PPNH telah dilakukan dengan baik. Asrama putra, asrama putri dan madrasah ibtidaiyyah memiliki satu bendahara, sebagai koordinator penerimaan dan pengeluaran kas. Ketiga bendahara tersebut, tidak secara khusus melakukan pencatatan atas aset tetap. Setiap penerimaan, pembelian barang, maupun pembayaran lainnya, secara rutin tercatat dalam suatu buku khusus dan menggunakan aplikasi khusus.

Pencatatan aset tetap berdasarkan Standar Akuntansi Keuangan yang berlaku di Indonesia belum dilaksanakan oleh PPNH. Mengidentifikasi aset tetap yang dimiliki oleh PPNH, dimulai dari mencatat bangunan, kendaraan, perlengkapan dan tanah yang digunakan dan atas milik PPNH. Untuk melakukan hal ini, dilakukan dengan mengunjungi lokasi aset, mengukur ulang, mencari dokumen pendukung dan mewawancarai bendahara maupun pihakpihak yang mengetahui langsung kondisi aset tersebut. Kegiatan pada tahap ini hanya mengidentifikasi nama, jenis dan jumlah/luas/berat dari aset tetap.

Proses berikutnya adalah menetapkan nilai saldo awal aset tetap. Nilai saldo awal digunakan untuk menyusun saldo awal laporan keuangan. Beberapa komponen aset tetap PPNH sudah ada sejak beberapa tahun lampau, seperti tanah, kendaraan dan bangunan. Catatan atas harga perolehan maupun harga wajar dari aset tersebut tidak dapat ditelusuri. Dengan keterbatasan tersebut, digunakan nilai wajar atas aset. Untuk aset berupa tanah, 
misalnya, digunakan nilai wajar terdekat, antara lain Nilai Jual Objek Pajak (NJOP) atau nilai harga jual tanah yang berlaku pada lokasi tanah tersebut. Nilai bangunan digunakan standar harga bangunan yang disusun oleh Kementerian Pekerjaan Umum. Hal yang sama dilakukan untuk semua jenis aset tetap. Hasil dari tahapan ini adalah daftar saldo awal aset tetap bagi PPNH.

Bagian ketiga dari kegiatan pengabdian pada masyarakat ini adalah meningkatkan pengetahuan bendahara atau asisten atau yang ditunjuk mengenai akuntansi aset tetap. Pelatihan mengenai akuntansi, dimulai dari persamaan dasar akuntansi dan kode akun bagi aset tetap. Penekanan pelatihan ini bukan pada proses penjurnalan. Bendahara kami latih untuk bisa mengidentifikasi pengeluaran kas atau non kas yang segera diakui di buku kas sebagai pembelian atau perolehan dan pemeliharaan yang meningkatkan nilai aset tetap. Transaksi penerimaan dan pengeluaran kas yang terjadi pada periode sebelum pelatihan dilaksanakan, menjadi obyek pelatihan peserta. Gambar 1 menyajikan proses diskusi dalam penentuan nilai aset tetap di PPNH.
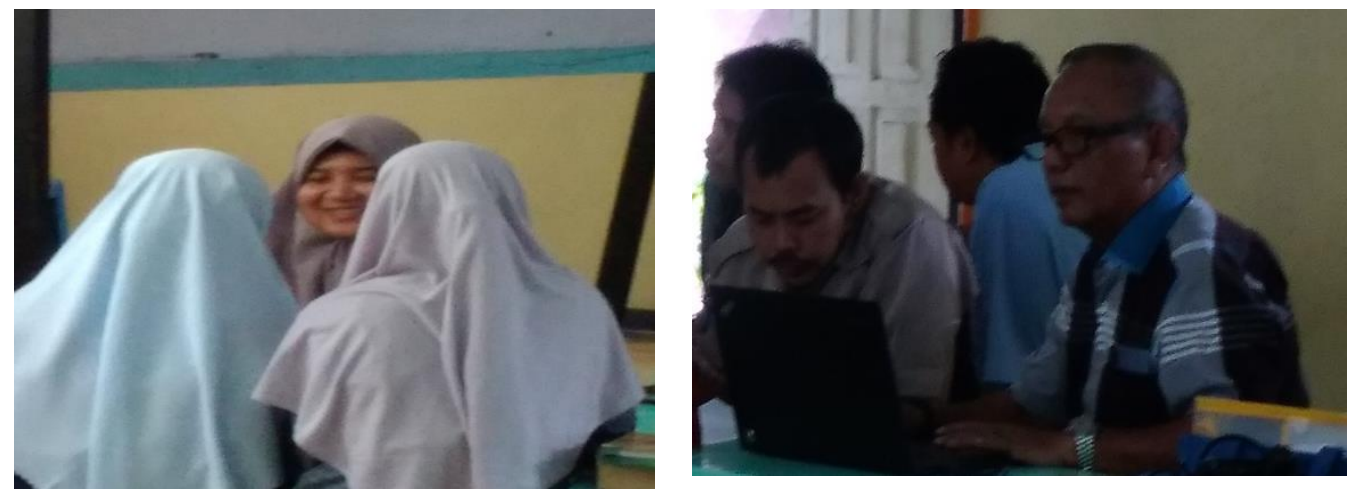

Gambar 1. Diskusi Penetapan Nilai Aset Tetap

Kebijakan manajemen atau pengelola PPNH terhadap pengakuan aset tetap turut didiskusikan dalam latihan. Kebijakan mengenai aset tetap meliputi jumlah minimal pengeluaran yang dapat diakui sebagai aset tetap atau jangka waktu penggunaannya. Tarif dan metode penyusutan aset tetap turut dibahas dalam diskusi. Tarif penyusutan aset tetap mengacu pada peraturan perpajakan yang berlaku.

\section{KESIMPULAN DAN SARAN}

\section{Kesimpulan}

Kegiatan pelatihan akuntansi aset tetap di PPNH dimulai dengan mengidentifikasi komponen aset tetap. Identifikasi aset ini meliputi, nama dan jenis, unit atau kuantitas serta lokasi aset tetap tersebut. Proses berikutnya adalah menentukan nilai atau saldo awal aset tetap. Pelatihan dilanjutkan dengan menentukan kebijakan akuntansi atas aset tetap.

Kegiatan pelatihan ini telah berjalan dengan baik. Diharapkan kegiatan ini dapat ditindaklanjuti oleh peneliti lain, di pondok pesantren yang berbeda, sehingga dapat mengembangkan transparansi dan pertanggungjawaban keuangan pesantren di masa mendatang. 


\section{Ucapan Terima Kasih}

Kami ucapkan terimakasih kepada Bank Indonesia dan Ikatan Akuntan Indonesia yang telah menerbitkan Pedoman Akuntansi Pesantren, serta mendorong terciptanya kemajuan pesantren. Pimpinan dan seluruh pengurus PPNH atas kerjasama dan dukungan yang diberikan dalam melaksanakan kegiatan pengabdian pada masyarakat ini. Ucapan terima kasih juga dihaturkan bagi Lembaga Penelitian dan Pengabdian Kepada Masyarakat Universitas Mataram, Lisa Ariani, Lalu Syamsul Hadi dan setiap pihak yang turut membantu terlaksanannya kegiatan ini.

\section{DAFTAR PUSTAKA}

Alhamudin, 1428 H. Pendidikan Islam Modern ala Trimurti Pondok Modern Darussalam Gontor. At-Ta'dib, 3(2), pp. 203-231.

Anwar, M. I., 2004. Administrasi Pendidikan dan Manajemen Biaya Pendidikan. 2 ed. Bandung: Alfabeta.

Arifin, M., n.d. https://www.academia.edu/32685163/manajemen keuangan pondok pesantren.

[Online]

Available at: https://www.academia.edu/32685163/manajemen keuangan pondok pesantren

[Accessed 11 Agustus 2019].

Indonesia, B. \& Indonesia, I. A., 2018. Pedoman Akuntansi Pesantren: Efekti per Mei 2018. 1 ed. Jakarta: Departemen Ekonomi Syariah Bank Indonesia.

Shiddiq, A., 2015. Tradisi Akademik Pesantren. Tadris, 10(2), pp. 218-229.

Subekti,

A.,

n.a.

Academia.

[Online]

Available

at:

https://www.academia.edu/12256839/KH._Imam_Zarkasyi_dan_Pemikiran_Pendidi kannya

[Accessed 19 Agustus 2019].

Yasid, A. et al., 2018. Paradigma Baru Pesantren: Menuju Pendidikan Islam Transformatif. 1 ed. Yogyakarta: IRCiSoD 